\title{
ANALISA KUALITAS PRODUK TERHADAP LOYALITAS KONSUMEN DENGAN KEPUASAN PELANGGAN SEBAGAI VARIABLE INTERVENTING PADA KONSUMEN SEPEDA MOTOR HONDA
}

\author{
Nur Aida ${ }^{1}$, Erlin Iriani ${ }^{1}$ \\ ${ }^{1}$ Sekolah Tinggi Ilmu Ekonomi Gempol Pasuruan \\ E-mail : nur.aidaph@gmail.com \\ http://doi.org/10.21107/pmt.v11i2.4771
}

\begin{abstract}
This research aimed to determine the effect of product quality to loyality with customer satisfaction as interventing variable. The population is someone who have Honda motor cycle because it used purpose sampling and the amount of sample $s$ are 60. Data were collected by spreading questionare. The data of the questioner's dissemination tested the validity, reliability and the result is valid and reliable. Result of hypothesis test that Product quality has direct and significant effect to customer satisfaction, product quality and customer satisfaction have direct and significant effect to loyality and there's significant influence of product quality to loyality trought customer satisfaction as interventing variable, in accordance with Sobel test where the value of $t$ arithmetic versus $t$ table of concluded that the coefficient of mediation significant.
\end{abstract}

Key Words : Product Quality, Customer Loyalty, Customer Satisfaction

\section{PENDAHULUAN}

Sepeda motor saat ini menjadi pilihan utama sebagian besar masyarakat sebagai alat transportasi sehari hari karena murah dan sangat efisien terhadap waktu tempuh apalagi harga bahan bakar semakin mahal dan hal ini membuat produsen sepeda motor berlomba lomba memproduksi kendaraan roda dua. Saat ini menurut data Asosiasi Industri Sepeda Motor (AISI) ada beberapa merk sepeda motor yang menguasai pasar : Honda, Yamaha, Suzuku, Kawasaki, Suzuki, TVS. Sepeda motor merk Honda saat ini masih menjadi market leader namun meihat pada pertumbuhan penjualan sepeda motor yang cenderung turun dari tahun 2015 sampai dengan tahun 2017 dan termasuk didalamnya pertumbuhan negative penjualan sepeda motor Honda maka harus dibuat strategi dan upaya untuk menjaga dominasinya dengan memberikan kepuasan konsumen dengan tetap mempertahan produk yang berkualitas sebagaimana dipersepsikan masyarakat.
Kotler dan Keller (2008) kunci keberhasilan pemasaran jangka panjang yang menjadi mimpi oleh semua pemasar adalah menciptakan hubungan nyang kuat dan erat dengan pelanggan. Banyak hal yang perlu diperhatikan guna memenangkna persaingan dan salah satunya adalah kualitas produk, karena kualitas produk mempunyai pengaruh dalam menciptakan kepuasan konsumen. Kualitas produk adalah penentu kepuasan konsumen setelah melakukan pembelian dan pemakaian suatu produk. Kualitas produk merupakan suatu bentuk dengan nilai kepuasan yang kompleks (Hidayat, 2009 dalam Irawan and Japarianto, 2013). Jika mutu produk yang diterima melebihi yang diharapkan, maka kualitas produk yang dipersepsikan akan memuaskan.

Menurut Umar (2008) kepuasan adalah respon pemenuhan dari pelanggan. Kepuasan merupakan penilaian dari pelanggan bahwa produk atau pelayanan telah memberikan tingkat kenikmatan dimana tingkat pemenuhan ini bisa lebih atau kurang. Pelanggan merasa puas apabila harapannya terpenuhi atau akan sangat puas jika harapan pelanggan 
terlampaui (Tjiptono, 2008). Pelanggan yang puas adalah pelanggan yang akan berbagi kepuasan dengan produsen atau penyedia jasa. Bahkan oleh karena itu, baik pelanggan maupun peritel, akan sama-sama diuntungkan apabila kepuasan terjadi. Dewasa ini kepuasan pelanggan telah menjadi bagian integral dalam misi dan tujuan sebagian besar organisasi. Meningkatnya intensitas kompetisi global dan domestik, berubahnya preferensi dan perilaku pelanggan, serta revolusi teknologi informasi merupakan sebagian diantara sekian banyak factor yang mendorong organisasi bisnis dan non bisnis untuk mengalihkan fokusnya ke arah customer oriented. Sebenarnya konsep kepuasan pelanggan masih abstrak. Pencapaian kepuasan dapat merupakan proses yang sederhana, maupun kompleks dan rumit. Dalam hal ini peranan setiap individu dalam servis encounter sangatlah penting dan berpengaruh terhadap kepuasan yang dibentuk. Untuk dapat mengetahui tingkat kepuasan pelanggan secara lebih baik, maka perlu dipahami pula sebab-sebab kepuasan (Nurlinda, 2013).

Kepuasan pelanggan bisa memberikan manfaat, seperti hubungan antara perusahaan dan pelanggan menjadi harmonis, pertimbangan yang baik bagi pembelian ulang dan menciptakan loyalitas pelanggan, serta membentuk suatu rekomendasi dari mulut ke mulut (word of mouth) yang menguntungkan bagi perusahaan (Tjiptono, 2008). Loyalitas merk pada konsumen tercipta karena kepuasan atau ketidakpuasan yang dirasakan pelanggan terhadap suatu merk yang terakumulasi terus-menerus disamping adanya persepsi tentang kualitas (Irawan dan Japarianto, 2013). Loyalitas (loyalty) sebagai komitmen yang mendalam dalam benak konsumen untuk membeli atau mendukung kembali produk atau jasa yang disukai di masa depan meski situasi dan usaha pemasaran berpotensi menyebabkan pelanggan beralih ke merk lain (Oliver dalam Kotler 2009).
Loyalitas sangat erat kaitannya dengan kepercayaan pelanggan terhadap suatu perusahaan.

Penelitian yang dilakukan oleh Djati (2004), menunjukkan bahwa kepercayaan dalam usaha merupakan sesuatu hal yang penting. Tanpa rasa percaya maka akan sulit bagi perusahaan untuk memiliki komitmen yang mendalam dengan perusahaan. Ketika perusahaan memiliki pelanggan dengan komitmen yang tinggi maka dikatakan perusahaan memiliki kemampuan yang signifikan untuk bertahan di dalam pasar. Sementara komitmen dari pelanggan diperoleh dari kepuasan pelanggan itu sendiri.

PT Astra Honda Motor (AHM) merupakan pelopor industri sepeda motor di Indonesia dengan sepeda motor merk Honda-nya yang terkenal namun kondisi persaingan yang begitu ketat dengan banyaknya merk-merk baru tentu membuat produsen sepeda motor Honda harus terus melakukan strategi-strategi yang tepat guna memenankan persingan. Dalam Corporate Profile PT AHM punya komitmen untuk memberi kualitas produk yang berupa sepeda motor yang tangguh, irit bahan bakar dan ekonomis. Dikatakan bahwa Visi dan Misi PT Astra Honda Motor adalah perusahaan yang menjalankan fungsi produksi, penjualan dan pelayanan purna jual yang lengkap untuk kepuasan pelanggan. PT AHM melalui OneHEART berkomitmen membuat sepeda motor yang mampu merefleksikan gaya kepribadian dan karakter konsumen bukan sepeda motor semata sebagai alat transportasi. Dari komitmen yang ditetapkan jelas terlihat bahwa PT AHM sangat konsern terhadap kualitas produk dan termasuk kepuasan dari para pengguna produk sepeda motor Honda dan dari segi loyalitas PT Astra Honda Motor pada tahun 2015 mampu mencapai puncak prestasi melalui tercapainya produksi ke 50 juta dan ini merupakan prestasi pertama yang diraih industri sepeda motor Indonesia bahkan untuk tingkat ASEAN.

- Rumusan Masalah

Berdasarkan uraian tersebut rumusan masalah pada penelitian ini adalah: 
1 Apakah terdapat pengaruh kualitas produk terhadap kepuasan konsumen sepeda Motor Honda.

2 Apakah terdapat pengaruh kualitas produk dan kepuasan konsumen terhadap loyalitas konsumen sepeda Motor Honda

3 Apakah terdapat pengaruh langsung kualitas produk terhadap loyalitas konsumen sepeda motor Honda.

4 Apakah terdapat pengaruh tidak langsung kualitas produk terhadap loyalitas konsumen melalui kepuasan konsumen sebagai variable interventing.

\section{- Tujuan Penelitian}

1. Mengetahui pengaruh kualitas produk terhadap kepuasan konsumen sepeda Motor Honda.

2. Mengetahui pengaruh kualitas produk dan kepuasan konsumen terhadap loyalitas konsumen sepeda Motor Honda

3. Mengetahui pengaruh langsung kualitas produk terhadap loyalitas konsumen sepeda motor Honda.

4. Mengetahui pengaruh tidak langsung kualitas produk terhadap loyalitas konsumen melalui kepuasan konsumen sebagai variable interventing

\section{METODOLOGI}

Tipe penelitian yang digunakan dalam penelitian ini merupakan tipe penelitian explanatory research, yaitu penelitian yang dilakukan untuk mengetahui hubungan antar variabel penelitian dan menguji hipotesis yang telah dirumuskan sebelumnya (Singarimbun, 1989).

\section{- Populasi dan Sample Penelitian}

Populasi adalah generalisasi dari subjek/objek yang mempunyai kualitas serta karakteristik tertentu sebagaimana ditetapkan oleh peneliti untuk dipelajari dan untuk ditarik kesimpulannya (Sugiyono 2013) dan populasi dalam penelitian ini adalah semua penggguna sepeda motor merk Honda berbagai tipe
Sampel adalah bagian dari populasi dimana sampel diambil dengan pertimbangan keterbatasan peneliti dalam hal waktu, biaya dan tenaga (Sugiono 2013). Roscow dalam Sekaran (1992) dikatakan jika populasi tidak diketahui jumlah sampel harus lebih besar dari 30 dan kurang dari 500 dan penelitian ini menggunakan sampel sebanyak 60 .

Teknik pengambilan sampel menggunakan non-probability Sampling yaitu teknik pengambilan sampel yang tidak memberi kesempatan atau peluang yang sama bagi setiap unsur atau anggota populasi untuk dipilih menjadi sampel (Sugiyono 2010) dan purposive sampling, yaitu pengambilan sampel dengan pertimbangan tertentu. Pertimbangan tersebut adalah; sampel merupakan pengguna sepeda motor Honda.

\section{- Jenis dan Sumber Data}

Sumber data dari penelitian adalah data primer, yaitu data yang diambil langsung dari responden melalui lang- sung melalui penyebaran kuesioner. Jawaban responden akan dinilai secara berjenjang mengingat data penelitian yang didapat berupa data kualitatif yang akan dikuantitatifkan dengan mengggunakan Likert lima poin yaitu: mulai dari Sangat Setuju ( $S S=5)$; Setuju $(S=4)$; Netral $(N=$ 3); Tidak Setuju (TS = 2) dan Sangat Tidak Setuju (STS =1). Variable dalam penelitian ini terdiri dari variable bebas yaitu variable kualitas produk sebagai $X$, variable terikat yaitu loyalitas konsumen sepeda motor Honda sebagai Y2 serta variable interventing yaitu Kepuasan konsumen Y1).

\section{- Uji Validitas dan Reliabilitas}

Uji validitas dilakukan apabila pengumpulan data dilakukan dengan cara menyebar kuestioner kepada responden. Uji validitas dimaksudkan untuk mengetahui apakah butir-butir pertanyaan dalam daftar pertanyaan mampu mendifinisikan variable (Sujarweni, 2015) dan butir-butir pertanyaa dikatakan valid apabila mempunyai nilai $r$ hitung $>r$ table. Uji reliabilitas merupakan ukuran 
kestabilan atau konsistensi responden dalam menjawab pertanyaan dalam kuestioner dan dikatakan kuestioner reliable apabila mempunyai nilai Alpha Cronbach > 0,6 (Sujarweni, 2015).

\section{- Uji Regresi dan Korelasi}

Dalam penelitian ini analisa regresi yang digunakan adalah regresi linier baik berganda maupun sederhana dengan persamaan sebagai berikut :

$$
\begin{array}{ll}
- & Y_{1}=a+b x+e 1 \\
- & Y_{2}=a+b_{1} x+e 2 \\
- & Y_{2}=a+b_{2} x+c y_{1}+e 3
\end{array}
$$

Dimana :

- $\quad Y_{2}=$ Loyalitas Konsumen

- $\quad Y_{1}=$ Kepuasan Konsumen

- $\quad X=$ kualitas produk

- $\quad$ bi = bilangan koefisien

- ei = jumlah variance yang tidak mampu dijelaskan oleh variable independen dimana nilai ei diperoleh dari rumus ei $=\sqrt{1-R^{2}}$

\section{- Analisa Jalur}

Analisa jalur digunakan untuk menguji pengaruh dari variable interventing dimana variable interventing adalah variable yang mempengaruhi hubungan antara variable bebas terhadap variable terikat menjadi sebuah hubungan yang tidak langsung. Dan variable interventing terletak yang letaknya diantara variable bebas dan terikat sehingga variable interventing tidak langsung menjelaskan atau mempengaruhi variable terikat.

\section{- Hipotesis Penelitian}

Hipotesis adalah jawaban sementara terhadap rumusan masalah penelitian, di mana rumusan masalah penelitian telah dinyatakan dalam bentuk kalimat atau pertanyaan (Sugiono, 2009). Berdasarkan pengamatan lapangan dan studi literature maka dapat dirumuskan hipotesis penelitian sebagai berikut :

1. Diduga terdapat pengaruh kualitas produk terhadap kepuasan konsumen sepeda Motor Honda.

2. Diduga terdapat pengaruh kualitas produk dan kepuasan konsumen terhadap loyalitas konsumen sepeda Motor Honda.

3. Diduga terdapat pengaruh langsung kuaitas produk terhdap loyalitas konsumen sepeda motor Honda.

4. Diduga terdapat pengaruh tidak langsung kualitas produk terhadap loyalitas konsumen melalui kepuasan konsumen sebagai variable interventing.

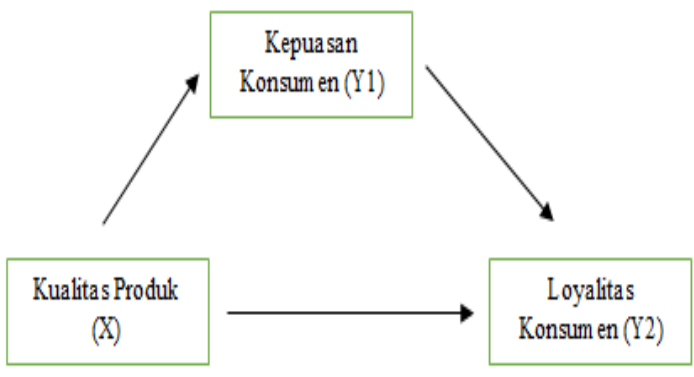

Gambar 1. Kerangka Penelitian

\section{HASIL DAN PEMBAHASAN}

Gambar 2 dibawah ini menunjukkan distribusi serta jumlah penjualan sepeda motor periode Januari 2007 - Juni 2017. Melihat pertumbuhan penjualan sepeda motor Honda pada grafik tersebut terlihat adanya fluktuasi. Pada kurun waktu tersebut, penjualan tertingi terjadi hulan Mei, sementara terendah pada bulan April dan Juni

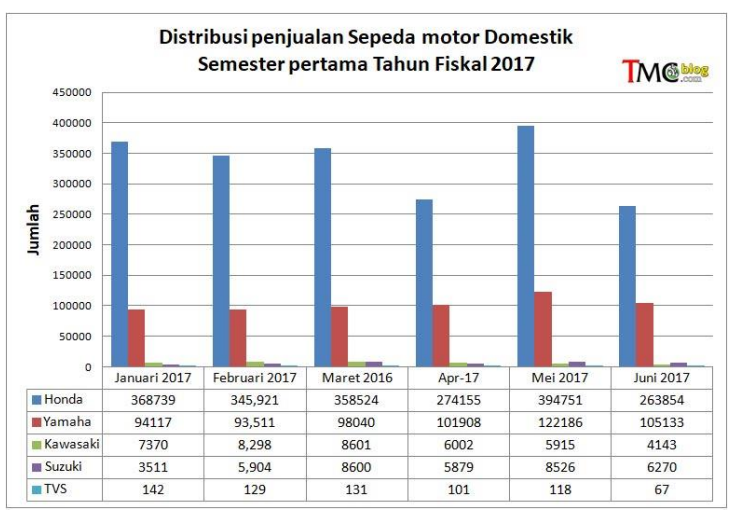

Gambar 2. Penjualan Motor Honda Januari-Juni 2017 
Tabel 1. Analisa Regresi Variable Kualitas Produk Terhadap Kepuasan

\begin{tabular}{|c|c|c|c|c|}
\hline $\begin{array}{c}\text { Koef. } \\
\text { Determinasi } \\
\left(\mathrm{R}^{2}\right)\end{array}$ & $\begin{array}{c}\text { Koef. Korelasi } \\
(\mathrm{r})\end{array}$ & F hitung & Sig & $\begin{array}{c}\text { Persamaan Regresi } \\
(\mathrm{Y}=\mathrm{a}+\mathrm{bx})\end{array}$ \\
\hline 0,401 & 0,633 & 45,577 & $<0,05$ & $\mathrm{Y}_{1}=2,271+0,518 \mathrm{X}$ \\
\hline
\end{tabular}

Penjelasan :

1. Koefisien regresi variabel kualitas produk $(X)$ adalah 2,271 dan bertanda positif, artinya setiap peningkatan kualitas produk sebesar satu-satuan akan meningkatkan kepuasan konsumen sebesar 0,518 satuan dengan asumsi variable lainnya dianggap tetap.

2. Korelasi antara kualitas produk terhadap kepuasan konsumen ditunjukkan oleh nilai $r$ dimana nilai korelasi hasil olah data adalah 0,633 yang artinya hubungan antara kualitas produk terhadap kepuasan konsumen kuat dan nilai $\mathrm{R} 2$ adalah 0,401 artinya kemampuan menjelaskan variable kualitas produk terhadap kepuasan konsumen adalah 40,1\% sementara sisanya sebesar 59,9\% dijelaskan oleh variable yang tidak masuk dalam variabel penelitian.

3. Artinya masih banyak variable yang menentukan tingkat kepuasan konsumen selain kualitas produk sebagaimana hasil penelitian (Nurlinda, 2013) bahwa kepuasan konsumen dapat disebabkan oleh relationship marketing, strategi superior customer service, strategi unconditional guarantee, strategi penanganan keluhan pelanggan dan strategi peningkatan kinerja perusahaan.

Tabel 2. Analisa Regresi Variable Kualitas Produk Terhadap Loyalitas

\begin{tabular}{|c|c|c|c|c|}
\hline $\begin{array}{c}\text { Koef. } \\
\text { Determinasi } \\
\left(\mathrm{R}^{2}\right)\end{array}$ & $\begin{array}{l}\text { Koef. Korelasi } \\
(r)\end{array}$ & Fhitung & Sig & $\begin{array}{l}\text { Persamaan Regresi } \\
(\mathrm{Y}=\mathrm{a}+\mathrm{bx})\end{array}$ \\
\hline 0,395 & 0,628 & 44,308 & $<0,05$ & $Y_{2}=1,862+0,524 X$ \\
\hline \multicolumn{5}{|c|}{$\begin{array}{l}\text { Penjelasan : } \\
\text { 1. Koefisien regresi variable kualitas produk }(X) \text { adalah } 1,862 \text { dan bertanda positif, artinya setiap } \\
\text { peningkatan kualitas produk sebesar satu-satuan akan meningkatkan loyalitas konsumen sebesar } \\
0,524 \text { dengan asumsi variable lainnya dianggap tetap. } \\
\text { 2. Korelasi antara kualitas produk terhadap loyalitas ditunjukkan oleh nilai r dimana nilai korelasi hasil } \\
\text { olah data adalah } 0,628 \text { yang artinya hubungan antara kualitas produk terhadap loyalitas konsumen } \\
\text { adalah kuat dan nilai } R 2 \text { adalah } 0,395 \text { artinya kemampuan menjelaskan variable kualitas produk } \\
\text { terhadap loyalitas konsumen adalah } 39,5 \% \text { sementara sisanya sebesar } 60,5 \% \text { dijelaskan oleh } \\
\text { variable yang tidak masuk dalam variabel penelitian. }\end{array}$} \\
\hline
\end{tabular}

Tabel 3. Analisa Regresi Antara Kualitas Produk Terhadap Loyalitas dengan Kepuasan Konsumen Sebagai Variable Interventing

\begin{tabular}{|c|c|c|c|c|}
\hline $\begin{array}{c}\text { Koef. } \\
\text { Determinasi } \\
\left(\mathrm{R}^{2}\right)\end{array}$ & $\begin{array}{c}\text { Koef. Korelasi } \\
(\mathrm{r})\end{array}$ & F & Sig & $\begin{array}{c}\text { Persamaan Regresi } \\
(\mathrm{Y}=\mathrm{a}+\mathrm{bx})\end{array}$ \\
\hline 0,779 & $\begin{array}{c}0,251 \text { (kualitas } \\
\text { produk) } \\
0,595 \\
\end{array}$ & 51,594 & $<0,05$ & $\mathrm{Y}_{2}=0,484+0,210 \mathrm{X}+$ \\
& $\begin{array}{c}\text { (kepuasan } \\
\text { konsumen) }\end{array}$ & & & $0,607 \mathrm{Y} 1$ \\
\hline
\end{tabular}

Penjelasan :

1. Nilai koefisien regresi variabel kualitas produk $(X)$ adalah 0,210 dan bertanda positif, artinya setiap peningkatan kualitas produk sebesar satu-satuan akan meningkatkan loyalitas konsumen sebesar 0,210 satuan dengan asumsi variabel lainnya dianggap tetap

2. Nilai koefisien regresi variabel loyalitas konsumen (Y1) adalah 0,362 dan bertanda positif, artinya setiap peningkatan kepuasan konsumen sebesar satu satuan akan meningkatkan loyalitas konsumen 0,362 satuan dengan asumsi variabel lainnya dianggap tetap.

3. Korelasi antara kualitas produk dan kepuasan konsumen terhadap loyalitas ditunjukkan oleh nilai $r$ dimana nilai korelasi hasil olah data adalah 0,779 yang artinya hubungan antara kualitas produk dan kepuasan konsumen terhadap loyalitas sangat kuat dan nilai $R^{2}$ adalah 0,606 artinya kemampuan menjelaskan kualitas produk dan kepuasan konsumen terhadap loyalitas adalah 60,6 $\%$ sementara sisanya sebesar $39,4 \%$ dijelaskan oleh variable yang tidak masuk dalam variabel penelitian. 


\section{- Penquiian Hipotesis 1}

Hasil pengujian pengaruh kualitas produk terhadap kepuasan konsumen pada tabel 7 diketahui bahwa nilai t-hitung variabel kualitas produk adalah 6,751 dan nilai t-tabel pada tingkat signifikansi $5 \%$ pada taraf uji dua sisi $(\alpha=, 05 / 2)$, dan degree of freedom $(\mathrm{n}-\mathrm{k}-1=70-1-1)=68$ diperoleh t-tabel sebesar 1,9955. Keputusannya adalah nilai t-hitung $(6,751)>$ t-tabel $(1,9955)$, sehingga menolak Ho atau menerima $\mathrm{Ha}$, berarti ada pengaruh signifikan kualitas produk terhadap kepuasan konsumen dapat diterima.

\section{- Pengujian Hipotesis 2}

Hasil pengujian pengaruh kualitas produk terhadap loyalitas konsumen pada table 10 diketahui bahwa nilai t-hitung variabel kualitas produk adalah 6,656 dan nilai t-tabel pada tingkat signifikansi $5 \%$ pada taraf uji dua sisi ( $\alpha=0,05 / 2)$, dan degree of freedom $(70-k-1=100-2-1)=$ 68 diperoleh t-tabel sebesar 1,9955. Keputusannya adalah nilai t-hitung $(6,656)>$ t-tabel $(1,9955)$, sehingga menolak Ho atau menerima $\mathrm{Ha}$, berarti ada pengaruh signifikan kualitas produk terhadap loyalitas konsumen.

\section{- Penqujian Hipotesis 3}

Dari hasil olah data didapat nilai standardized beta kualitas produk sebesar 0,518 dan nilai signifikan pada 0,000 yang berarti kualitas produk mempunyai pengaruh terhadap kepuasan konsumen dan nilai koefisien beta sebesar 0,518 merupakan nilai dari jalur $\mathrm{p}_{1}$. Dari hasil olah data didapat nilai standardized beta kualitas produk sebesar 0,210 dan kepuasan konsumen sebesar 0,607 dan nilai koefisien beta sebesar 0,210 merupakan nilai jalur $\mathrm{p}_{2}$ dan nilai koefisien beta sebesar 0,607 merupakan nilai dari jalur $\mathrm{p}_{3}$ Besar nilai $\mathrm{e} 1=\sqrt{(1-0,401}=$ 0,774 sedangkan besar nilai $\mathrm{e} 2=$ $\sqrt{(1-0,606}=0,628$.

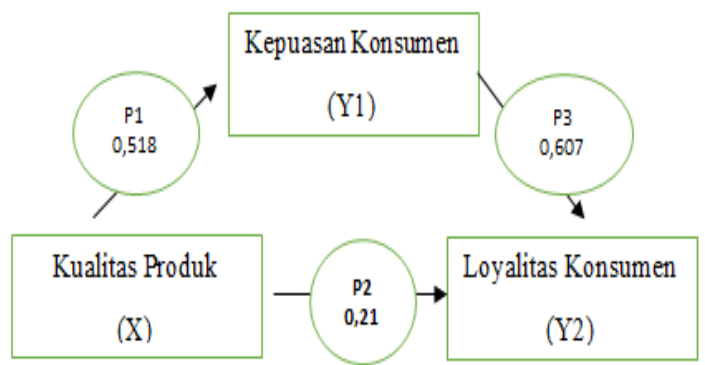

Gambar 3. Hasil Analisa Jalur (Path Analysis)

Pengaruh langsung kualitas produk adalah 0,210 sedang pengaruh tidak langsung kualitas produk terhadap loyalitas konsumen didapat dengan mengalikan pengaruh langsung tersebut dengan koefisien tidak langsung yaitu $0,518 \mathrm{x}$ $0,607=0,314$ sehingga didapat nilai total pengaruh $0,210+0,314=0,832$.

Didapat sebuah kesimpulan bahwa nilai dari pengaruh langsung lebih kecil dibandingkan nilai dari pengaruh tidak langsung dengan kepuasan konsumen sebagai variable interventing.

Untuk mengetahui signifikan tidaknya variable interventing yaitu kepuasan konsumen dapat dilakukan melalui uji Sobel dengan perhitungan sebagai berikut Sp $2 p 3=\sqrt{p 3^{2} S p 2^{2}+p 2^{2} S p 3^{2}+S p 2^{2} S p 3^{2}}$

Sp $2 p$ 3= $\sqrt{(0,607)^{2}(0,077)^{2}+\left(0,210^{2}(0,101)^{2}+(0,077)^{2}(0,101)^{2}\right.}$ Sp 2p $3=\sqrt{0,0022+0,00045+0,00006}=0,0521$ Nilai t hitung pengaruh variable interventing adalah

$$
\mathrm{T}=\frac{p 2 p 3}{s p 2 p 3}=\frac{0,314}{0,0521}=6,03
$$

Nilai thitung 6,03 lebih besar dibandingkan nilai t table sebesar 1,9955 dengan tingkat signifikansi 0,05 dua arah maka dapat disimpulkan bahwa koefisien mediasi 0,314 signifikan artinya ada pengaruh variable kepuasan konsumen sebagai variable interventing terhadap loyalitas. Hal ini sesuai dengan (Putri, Suharyono and Fanani, 2015) bahwa kepuasan konsumen Auto2000 sudah dirasakan akan membuat pelanggan menceritakan pengalaman yang baik kepada orang lain dan ini merupakan kunci dari terjadinya pembelian ulang oleh konsumen dimasa mendatang. 
Menurut Sumarwan (2010) kepuasan adalah tingkat perasaan setelah membandingkan kinerja/hasil yang dirasakan dengan harapannya. Dengan demikian tingkat kepuasan merupakan fungsi dari perbedaan antara kinerja yang dirasakan dengan harapan. Apabila kinerja di bawah harapan, maka pelanggan akan kecewa, bila kinerja sesuai dengan harapan, maka pelanggan akan sangat puas.

Kotler (2003) menambahkan bahwa kepuasan konsumen adalah tingkatan perasaan seseorang setelah mengkonsumsi sebuah produk, dengan membandingkan antara performa produk dengan yang diharapkan dari produk. Oleh karena itu kepuasan dapat dibagi menjadi tiga tingkatan yaitu :

1. Tidak puas (dissatisfied), terjadi bila performa produk yang dirasakan lebih kecil daripada harapan konsumen.

2. Puas (satisfied), terjadi apabila performa produk yang dirasakan sebanding dengan yang diharapkan konsumen.

3. Sangat puas (highly satisfied), terjadi saat konsumen merasakan performa produk melebihi dari apa yang diharapkan sebelumnya

Sejumlah studi menunjukkan bahwa ada tiga aspek penting yang perlu ditelaah dalam kerangka pengukuran kepuasan pelanggan (Tjiptono, 2008), yakni (1) kepuasan general atau keseluruhan (overall satisfaction) (2) konfirmasi harapan (confirmation of expectation) yakni tingkat kesesuaian antara kinerja dengan ekspektasi; dan (3) perbandingan situasi ideal (comparison to ideal), yaitu kinerja produk dibandingkan dengan produk ideal menurut persepsi konsumen.

Loyalitas pelanggan adalah komitmen pelanggan terhadap suatu merek, toko, atau pemasok, berdasarkan sikap yang sangat positif dan tercermin dalam pembelian ulang yang konsisten. Berdasarkan definisi tersebut dapat di ambil kesimpulan bahwa loyalitas pelanggan adalah sikap positif pelanggan yang mengkonsumsi produk atau jasa sebuah perusahaan dengan disertai komitmen untuk membeli secara konsisten dan terus menerus produk atau jasa perusahaan tersebut. Manfaat loyalitas pelanggan menurut adalah : (1) mengurangi biaya pemasaran, karena biaya untuk menarik konsumen yang baru tidak murah; (2) menurunkan biaya transaksi; (3) menurunkan biaya perputaran konsumen, karena pergantian konsumen yang lebih sedikit; (4) menaikkan penjualan silang yang akan memperbesar pangsa pasar perusahaan; (5) menciptakan word of mouth yang lebih positif, diasumsikan bahwa konsumen yang merasakan kepuasan akan menjadi konsumen yang loyal; (6) mengurangi biaya kegagalan (seperti biaya penggantian dan lain-lain).

\section{KESIMPULAN}

1. Ada pengaruh kualitas produk terhadap kepuasan konsumen karena terbukti dari nilai nilai t-hitung $(6,751)>$ t-tabel $(2,003)$ artinya kualitas produk sepeda motor Honda harus terus dipertahankan karena terbukti kualitas mempunyai pengaruh yang cukup kuat terhadap kepuasan dengan nilai $r$ 0,633. Namun dari nilai $R$ terlihat bahwa kemampuan menjelaskan variable kualitas terhadap kepuasan konsumen hanya 40,1\% artinya $59,9 \%$ kepuasan ditentukan oleh variable lain sehingga bagi produsen maupun pihak dealer harus dicari variable sebagaimana penelitian Nurlinda (2013) bahwa kepuasan konsumen dapat disebabkan oleh relationship marketing, strategi superior customer service, strategi unconditional guarantee, strategi penanganan keluhan pelanggan dan strategi peningkatan kinerja perusahaan.

2. Ada pengaruh kualitas konsumen terhadap loyalitas konsumen terbukti dari nilai t-hitung $(6,656)>$ t-tabel $(2,003)$, artinya kualitas produk harus terus diperhatikan karena mempunyai korelasi ( $r$ ) sebesar 0,628 yang berarti hubungannya cukup kuat namun kemampuan menjelaskan variable 
kualitas terhadap loyalitas hanya 39,5\% artinya $60,5 \%$ loyalitas diterangkan oleh variable lain dan ini mengandung arti bahwa untuk menciptakan konsumen yang loyal tidak cikup hanya memberikan kualitas produk yang baik saja karena memang tidak mudah menciptakan konsumen yang loyal.

3. Ada pengaruh kualitas produk terhadap loyalitas konsumen dengan kepuasan konsumen sebagai variable interventing sesuai dengan hasil uji Sobel dimana $t$ hitung 6,03 lebih besar dibandingkan nilai $t$ table sebesar 2,0003 dan koefisien mediasi 0,314 signifikan artinya ada pengaruh variable kepuasan konsumen sebagai variable interventing terhadap loyalitas. Untuk menciptakan konsumen yang loyal pada produk Honda maka produsen Honda harus mampu menciptakan kualitas yang baik sehingga konsumen menjadi puas.

\section{DAFTAR PUSTAKA}

Gale, T. 1997. Managing Customer Value: Creating Quality \& Service That Customer Can See. The Free Press. New York.

Ghozali, I. 2016. Aplikasi Analisis Multivariate dengan Program IBM/SPSS 23 (8th edition). Badan Penerbit Universit as Diponegoro. Semarang.

Irawan, D \& Japarianto, E. 2013. Analisa Pengaruh Kualitas Produk Terhadap Loyalitas Melalui Kepuasan Sebagai Variabel Intervening Pada Pelanggan Restoran Por Kee Surabaya. Jurnal Manajemen Pemasaran. Vol. 1 No. 2, pp. 1-8.
Kotler, P \& Armstrong, C. 2008. PrinsipPrinsip Pemasaran (Edisi ke-12). Erlangga. Jakarta. 2008.

Kotler, P. 2003. Marketing Management, 11th Edition. Prentice Hall. New Jersey.

Kurniawati, D. 2014. Kepuasan dan Loyalitas Pelanggan (Studi pada Pelanggan KFC Cabang Kawi Malang). Jurnal Pemasaran. Vol. 14 No. 2. pp. 1-9.

Nurlinda, R.A. 2013. Pengaruh Customer Satisfaction Strategy Terhadap Peningkatan Kepuasan Konsumen. Forum IImiah. Vol. 10, No. 2. pp. 172181.

Sekaran, U. 2006. Research Methods For Business (4th edition). Salemba Empat. Jakarta.

Shahid, Z., Hussain, T \& Zafar, F. 2017. The Impact of Brand Awareness on the Consumers' Purchase Intention. Journal of Accounting Mark. Vol. 6. No. 1, pp. 1-4.

Sugiono. 2009. Metode Penelitian Bisnis (Pendekatan Kuantitatif Kualitatif). Alfabeta. Bandung.

Sugiono.2013. Statistika Untuk Penelitian. Alfabeta. Bandung.

Sujarweni, V.W. 2015. Statistik untuk Bisnis \& Ekonomi. Pustaka Baru Press. Jogjakarta.

Suprapto. 2006. Pengukuran Tingkat Kepu asan Pelanggan untuk Meningkatkan Pangsa Pasar. PT Rineka Cipta. Jakarta.

Tjiptono, F. 2008. Strategi Pemasaran. (Edisi ke-3). Penerbit Andi. Yogyakarta. 
